\title{
Who is Telling the Tale? A Narratological Reading of the Roles of the Narrators in Lemony Snicket's A Series of Unfortunate Events and Qarun
}

Heidi Mohamed Bayoumy

Assistant Professor, Faculty of Arts, Cairo University, Egypt.

\begin{abstract}
Narration plays an important role in dramatic works. Classic critics, most prominently Aristotle, have always focused on acting despite narration playing a significant role, often presented through flashbacks, news, brief or long interludes. Brian Richardson, well-known for his articles on narrativity and drama strongly affirms that "drama, like the novel, is and always has been a mixture of mimetic and diegetic representation" (193). Fludernik also asserts that "it is ... customary to analyse not only the novel and the film as narrative genres but also drama, cartoons, ballet and pantomime" (4). Drama and film thus combine "seeing" and "narrating" side by side. Narration is often used by playwrights and scriptwriters to shed light on important functions/messages: creating an alienating effect, storytelling, interrupting and/or commenting on the events. Such functions highlight the presence of the narrator who emerges as a figure worthy of analysis given the fact that he takes different forms and names: messenger, chorus, or even a character. In plays and films for young
\end{abstract}

adults, the narrator is of extreme importance as he has a centralised role in introducing and ending the play/film and often intervening for commentary. The narrator's identity and his vital and diverse roles can be clearly seen in two works for young adults (a film and a play): Lemony Snicket's A Series of Unfortunate Events (2004) and Qarun (2018). These works have been selected because they have not been critically dealt with and because narration is interwoven with the events of the works and is, therefore, strongly present. Moreover, the narrators perform different, but significant roles that, in turn, influence the way the event, story or tale being told. For a thorough reading and analysis of these roles, the paper will employ the principles of narratology as a theoretical framework to approach the selected works in order to highlight the significant roles of the narrators and how they effectively present the events of the plays and film to the young adult audience/viewers.

Keywords: narratology, narration, narratives, young adult literature, Drama, Films for young adults, 


\section{Who is Telling the Tale? A Narratological Reading of the Roles of the Narrators in Lemony Snicket's A Series of Unfortunate Events and Qarun}

Heidi Mohamed Bayoumy

Until recently, drama has been viewed as a strictly performative form of literature that is separate from other narrative forms. Gradually, as Fludernik asserts, it has become "customary to analyse not only the novel and the film as narrative genres but also drama, cartoons, ballet and pantomime" (4); thus, proving how the "longstanding dichotomy between narrative and drama is an artificial one" (Wout Dillen 69). Brian Richardson, wellknown for his articles on narrativity and drama strongly affirms that "drama, like the novel, is and always has been a mixture of mimetic and diegetic representation, and that any theory of narration that ignores stage narration may be considered needlessly limited, if not seriously impoverished" (212). He adds that "One oddity of literary theory that needs to be rethought is the belief that narrators and narration do not exist in drama, but are found exclusively in narrative fiction proper? A belief which in one form or another stretches back to Plato and Aristotle" (Brian Richardson 690). Throughout the ages, narration has always been present in drama and film in the forms of flashbacks, news, brief or long interludes, to shed light on important functions/messages: creating an alienating effect, storytelling, interrupting and/or commenting on the events. Such functions highlight the presence of the narrator who emerges as a figure worthy of analysis given the fact that he takes different forms and names: messenger, chorus, or even a character. In plays and films for young adults, the narrator is of extreme importance as he has a centralised role in introducing and ending the play/film and intervening for commentary. The narrator's vital and diverse roles can be clearly seen in two works for young adults: first, the American film Lemony Snicket's A Series of Unfortunate Events (2004) directed by Brad Silberling and the screenplay is by Robert Gordon. The film is an adaptation of a series of books; namely, The Bad Beginning (1999), The Reptile Room (1999) and The Wide Window (2000). The second selected work is the Egyptian play Qarun (2018) written in Arabic by Asmaa Abu Taleb, an academic and a story writer for children. She has written a number of poetic plays for young adults and short stories for children such as The Intelligent Cock, The Big Tree, The Stubborn Fly. Both works have been selected because they have not been critically dealt with and because narration is interwoven with the events of the works and is, therefore, strongly present. Moreover, the narrators perform different, but significant roles that, in turn, influence the way the story or tale is being told. For a thorough analysis of these roles, the paper will employ the principles of narratology as a theoretical framework to approach the selected works in order to highlight the significant roles of the narrators and how they effectively present the events of the play and film to the young adult audience/viewers. 


\section{Drama, Film, Narration}

What is a narrative? Because of the polysemy of the term, a number of definitions have been proposed by various scholars and critics. One simple definition that stands out is that of Gerald Prince who believes that narrative is "the recounting of at least two real or fictive events (or one situation and one event) neither of which logically presupposes or entails the other" (1955).

A more elaborate definition of narrative is that of Fludernik who states that

A narrative ... is a representation of a possible world in a linguistic and/or visual medium, at whose centre there are one or several protagonists ... It is the experience of these protagonists that narratives focus on, allowing readers to immerse themselves in a different world and in the life of the protagonists. ...The narrator or narrative discourse shape the narrated world creatively and individualistically at the level of the text, and this happens particularly through the (re)arrangement of the temporal order in which events are presented and through the choice of perspective (point of view, focalization). (7)

Based on the previous definitions, the word "narrative" means a tale told or delivered by a narrator whose task is to impart whatever tale, story or news (depending on the medium or genre) to an intended audience. The word "narrator" is defined in the Dictionary of Narratology as 'the one who narrates, as inscribed in the text" (1963). The narrator's presence in any work entails the existence of a naratee/audience defined by Fludernik as "the intrafictional addressee of the narrator's discourse. S/he may also be a fictional character: the narrator tells the story to a friend, for instance, in other words to someone who belongs, just as the narrator does, to the fictional world" (23). Given the different and unique nature of drama, the type of narrators in different plays needs to be thoroughly examined. As Jahn believes, there are two types of narrators in drama: first, the "overt teller figure (like, say, Gower in Pericles, Tom in The Glass Menagerie, or the Stage Manager in Our Town), ... [the second is] an impersonal, covert shower" (670). Based on the previous view, in drama, the narrator emerges as either an outsider to the imparted tale and events or an insider, whose mere commentary on the events suggests that he is a witness to all the past and ensuing events. As for films, the narrator, according to Fludernik, "is comparable to the narrator in the novel and fulfils a similar mediating function in the presentation of the story" (6). His presence in films suggests that all the events that the viewers are about to witness are told from his own perspective and that all the cinematic techniques: camera angels, light, types of shots are all employed to convey this point of view. According to Seymour Chatman, "the narrator's presence [in films] is only salient at the moment he or she speaks. Otherwise, the combined force of the diegetic visual and sound images dominate, giving the impression that things are happening right there before us" (qtd. in Richardson 685). Chatman's view of the sense of immediacy is what connects drama and film. Together, they fall into the category of "mimetic narratives," unlike "'diegetic narratives' [which comprise] novel, epic, and short story" (Jahn 669). Because of such categorization, critics and scholars examine narration in both genres/media. 
Narrative theory or narratology is "the study of narrative structure" (Gary Steinley 311). It is "the study of narrative as a genre. Its objective is to describe the constants, variables and combinations typical of narrative" (Fludernik 8). How narration is delivered and in what ways is the focus of this paper which will probe two selected works that target young adults. Young adult literature is a literature that addresses readers/viewers whose age ranges from twelve to eighteen years old (Michael Cart 76). According to Alice Trupe, "Contemporary Young Adult (YA) literature is a comparatively new field, usually dates by scholars to the publication of S. E. Hinton's The Outsiders (1967), when the author was seventeen... The genre of YA literature has thrived since 1960s, though critical recognition and scholarly interest has lagged a bit behind" (vii). She adds that "by some definitions, 'young adults' include people in their early twenties" (viii). Crag Hill also believes that Young Adult Literature is one "that focuses on adolescence - young people in the midst of transition" ( $\mathrm{x}$ ). The two selected works that target young adults are Lemony Snicket's A Series of Unfortunate Events and Qarun. Lemony Snicket's A Series of Unfortunate Events is an adaptation of the books written by Lemony Snicket, the pen name of Daniel Handler who wrote a number of works: The Basic Eight, Watch Your Mouth and Why We Broke Up. The film won a number of wards: Academy Awards for Best Makeup and Hair 2005, Teen Choice Award for Choice Movie Villain 2005, and Australian Film Institute International award for Best Actress 2005. The film exposes the ordeal of the three siblings: Violet, Klaus and Sunny, who lost their parents and house in a fire. They later on discover that the arson was caused by
Count Olaf, the distant cousin and the villain in the film, who wishes to have their fortune.

Qarun (2018), by Asmaa Abu Taleb, is an adaptation of the Qur'anic tale of Qarun, one of the Israelites who lived at the time of Moses. Historically speaking, Qarun, or Korah as known in the Old Testament, was known for his incredible wealth and power; a tycoon who had no compassion for the poor. In Stories of the Prophets, Ibn Kathir states that "Ibn Abbas said: Qarun was the cousin of Moses... Qatada said: he was called "The Light" because of his nice voice when reading the Torah. But ... hypocrisy destroyed him and the main cause of his destruction was the multiplicity of his money" (430). Rapheal Patai states that "in the midrash ... Korah's riches derived from his having discovered one of the treasures Joseph had hidden in Egypt. He perished because of his rapacity" (24-25). Qarun always "flaunted his wealth and considered himself superior to his people" (Zeki Saritoprak 25). Therefore, his ending, being "swallowed by the earth" as stated in the Holy Quran, is a punishment for hoarding his money and denying the poor a share of his wealth.

In both works, the narrators tell the young audience the tales of the Baudelaires and of Qarun hoping that they would learn a moral lesson from it. It is the purpose of this paper to examine the two works from a narratological perspective analysing the roles of the narrators and the functions of the narratives.

\section{Introducing/ Elaborating/ Contextualising}

The narrators in the selected works perform various significant roles. From a narratological perspective, one important 
"naratological category," according to Woud Dillen, that stands out when discussing their functions is "voice ("who speaks)" (78). Questions evolving around the identity of the narrators in both works are very important to be posed by the audience/viewers from the beginning of the works. In Qarun, the identity of the narrator remains anonymous till the very end of the play. Is he a friend/foe of Qarun? Is he another Sheikh like Sheikh Saleh? Should we consider him a foil to Qarun? These are questions that remain unanswered till the end. The narrator effects a sense of ambiguity as he never tells his audience who he really is and this compels the audience to reflect upon his words and contemplate his reliability as a narrator. The only description provided of him is in the stage directions at the outset of the play: "enters the narrator, an old man with white beard, his features reflect that he is a good man" (4). Such description allows the children to believe that this old man's commentary later on reflects his wisdom and experience.

As for the film, the narrator introduces himself to his viewers as: "my name is Lemony Snicket." The name of the narrator is itself the pen name of the author of the original book; this creates an overlap between the author and narrator. In Lemony, the viewers understand that what they witness is the recollections of the narrator who is both narrating the events and typing them; affirming that he is both the author and narrator. The duality in Lemony is problematic as it creates a narrative inside a narrative (metanarrative): a biography or account of what happened existing side by side and through the narrative frame of the film. The complexity of the layers of the authornarrator and of the genres present (narrative-film) are further complicated when he interrupts his own writing/narrative, as will be stated in the second part of the paper. Significantly, as a narrator, Lemony Snicket never explains how he is related to the children except at one point when he says:

No one knows the precise cause of the Baudelaire fire. My colleagues and I

have investigated the best we can. But all we've discovered is that the blaze

was started from a great distance through the refraction and convergence of light.

It is only through the above lines that the audience knows that he is fully aware of what happened to the parents. In fact, it is the readers of the novel who are able to decipher the enigmatic presence of the narrator and how he is connected to the orphans in the work. In the book, the narrator was once in love with the protagonists' mother, who broke off with him and married Baudelaire. After she and her husband died, Lemony felt responsible to record this sad tale of the children. Parallel to the narrator in Qarun, there is a sense of mystery that envelopes Snicket who is indistinctly viewed. The camera almost always shows him as he is typewriting his story, but never in full view. The lighting in the film plays an important role whenever the narrator emerges as it is always slightly dim. No close-ups are used and; therefore, the narrator's face is never fully revealed. This visual concealment is done to clarify how he is outside the events and; thus, to compel the viewers to focus on the children protagonists and what befalls them. 
Together, both narrators can be described as "generative narrators," a term that Wout Dillen defines as narrators "whose diegetic discourse engenders the ensuing mimetic action.' In other words, it is a character that introduces a story which is then in turn enacted on stage" (72). Moreover, both narrators can also be seen as "heterodiegetic" narrators who are "agents that are external to the storyworld" (Richardson 682). Because they are both generative and hererodiegetic, they perform a number of roles throughout the works. They, to borrow Jahn's words on the narrator in the Perciles, "Introduce [themselves] as a narrator figure[s] on the communicative level of fictional mediation, ... [showing] narratorial 'conative solicitude' ... address the audience, ..., advertise the story's didactic purpose as well as its proven entertainment value, add some verbal decor which establishes story-HERE and story-NOW, and finally ask the spectators to see and judge for themselves" (671). In Qarun, the narrator, from the beginning of the play, informs his audience of the tale they are about to listen/watch:

Narrator: Good evening to all members of the auditorium,

Ladies and Gentlemen,

Old and young,

People of all ages.

The tale we will tell today will be honestly narrated.

It is a Quranic story that, despite the passage of time,

has become a real example of a proud tyrant,

Who never showed mercy to the orphans,

Was never a philanthropist,

But was unjust to the poor.

So, let's listen and silently watch
To understand what will take place.

Let's sail through time and see the past now on stage (4). ${ }^{1}$

Such introduction is needed to orient the audience and prepare them for the advent actions. Gradually, another introduction, marked with the change in the lighting as stated in the stage directions, is made: "The light gradually dims and is centered on the narrator. A screen backstage shows the following lines from the Holy Quran: "Qarun was one of Moses' people, but he oppressed them. We had given him such treasures that even their keys would have weighed down a whole company of strong men" (5). The narrator then proceeds to provide his audience with further description of the central character in the play:

Narrator: Because God is the Giver,

He provided Qarun with wealth and power,

But denied him the love of people, Because God gives love to those who have love and show love.

Qarun was stingy, never gave in

To the pleading/begging of a hungry beggar moaning (5).

The mere presence of the Quranic verse as a visual sign supports his words. Throughout the description, the setting is outside the palace. The moment Qarun emerges on stage, the setting changes and it is inside his grand palace. This change further proves the nature of the narrator as heterodiegetic. As for time, he incisively situates the audience into the age in which the events of the tale took place. Ricoeur affirms that "the matter of time plays an important role [in narratives]..., because our understanding of narratives is 
grounded in temporal experience, at the level of reading and at the level of existing" (Time and Narrative 5). Asserting time and its relation to the present is one of the functions performed by the narrator while introducing his tale. He asserts to the here and now audience that this tale occured during the time of Moses and the Israelites and that it is taken from the Holy Quran. His narrative thus sets the boundaries of time and place. The audience never sees Qarun as a child or a juvenile, but as an adult. The play follows the Aristotelian Unity of Time occurring in just one day and, by sunset, Qarun's palace is destroyed. Witnessing the last day, the narrator's task is arduous as he is compelled to expose his stinginess and covetousness and his fall within very limited time. Hence, the audience is immediately immersed into the events and Qarun fully exposes himself in a monologue. Without his appearance, the narrator's task would be incomplete. Hence, after his words, an enactment of Qarun's previously listed failures and flaws are witnessed on stage. To validate the narrator's earlier description of Qarun, the light changes, a clear semiotic indexic sign pointing to the central figure. Therefore, the narrator, who has a centralized function, is guiding the audience to the protagonist of the tale whose verbal and non-verbal signs quickly assert the earlier prerogatives and presuppositions of his covetous and avaricious love for money:

Qarun [singing while looking at his money]: Good morning my dears, My good luck,

You are all I dream of,

The joy of my life,

My support,

My heart's joy,
And when I'm old, you are the best of friends and family (6-7).

The narrator's earlier words, supported by Qarun's self-exposition, help the audience to materialize, assimilate and fathom the complexities of the tale and of the character. The narrator has therefore performed a number of tasks with his opening speech: introducing Qarun, centralizing him, and directing the audience's attention to what follows.

In Lemony, the narrator also begins and ends the tale, but he never informs the audience of the exact time and year of the tale; thus, giving his narrative a universallike appeal and effect. Fludernik states that "In film versions of literary texts one often finds framing narrator figures: they feature in voice-overs or in a sequence inserted at the beginning of a film showing the firstperson narrator writing the text. In some films, the level of narration is transposed into the film" (35). In Lemony, unlike Qarun, the narrator does not emerge before the viewers in the opening scene of the film. Instead, his voice is heard announcing that the tale he is about to narrate is a sad one. In fact, the film opens with another film showing a happy elf; the narrator then interrupts saying:

I'm sorry to say that this is not the movie you will be watching. The movie you are about to see is extremely unpleasant. If you wish to see a film about a happy little elf, I'm sure there is still plenty of seating in theater number two.

However, if you like stories about clever

and reasonably attractive orphans, suspicious fires, carnivorous leeches, 


\author{
Italian food \\ and secret organizations, \\ then stay \\ as I retrace each and every one \\ of the Baudelaire children's \\ woeful steps.
}

The narrator is thus creating a narrative within a narrative. Soon, Lemony is seen typing his tale and, like his counterpart in Qarun, provides a thorough description of the protagonists who are three orphans suffering from the loss of their parents in an arson:

Violet Baudelaire, the eldest, was one of the finest 14-year-old inventors in the world.

\section{Klaus Baudelaire, the middle child,} loved books.

Or, rather, the things he learned from books.

Sunny, the youngest, had a different interest.

She liked to bite things and had four sharp teeth.

With every detailed description of the three orphans, the camera shows the child described. The narrator's voice and the camera movement become the means of centralizing the children, one at a time. This alliance of the image and voice continues throughout the film, but is often violated. At times, Lemony's words act as a prelude to what will happen to the children and the following shot exemplifies his words. However, at other times, this order is disrupted to make the narrator's basic function of commenting on the events crystalized. This desynchronized method is done to compel the audience to focus on whatever the message the author/director wishes to convey.

Interestingly, both narrators do not use flashbacks or any enactment of past events. They are the ones who simply provide very brief information of their characters' past as their interest lies in compelling the audience/viewers to focus on the present of the protagonists. Significantly, both narrators do not merely introduce their characters, but they fully expose them to the audience/viewers; thus, emerging as, "authorial narrators." According to Fludernik, an "authorial narrator" is a "prominent narrator persona who tells us quite explicitly what is what, introducing scenario and setting, evaluating the dramatis personae with no uncertain strokes of the pen, and maintaining an ongoing bantering exchange with the reader in the form of exhortation. This type of narrator is not part of the fictional world, but stands above it" (124). Fludernik adds that such a narrator is both "a heterodiegetic and extradiegetic narrator figure ... knows the past, present and future of his characters, can move between locations at different ends of the fictional world, and has unlimited access to characters' minds" (124). In both works, the narrators' description of the characters prove that they are indeed aware of what their characters think, feel or experience. In fact, while providing such description, the narrators adopt different techniques. According to Fludernik, there are three ways in which a narrator exposes the feelings and emotions of his characters: "a quasi-direct representation of thoughts in free direct thought ... which is characterized by the use of first-person pronouns and finite verbs (present tense); the representation of thought in free 
indirect thought/discourse" and "psychonarration ... in which the verbs and nouns used indicate mental processes" (82). In the film, psycho narration is the first type exposed at the very beginning of the film after the children discover their parents' death in the fire:

But as Klaus now realized, the smallest discovery would send his mind reeling with questions. What was this spyglass hidden in his father's desk?

Were there other secrets about their parents' lives yet to be revealed?

Questions he now feared might never be answered.

The reason behind such narration is to underscore how the minds of the children are filled with unanswered questions and confusing thoughts. Thus, the focus on the emotions is delayed till later on when the use of "representation of thought/ free indirect thought" is strongly present to create empathy for the protagonists and to highlight their "misfortunes" because Count Olaf has become their custodian:

"Sanctuary"

is a word which here means, "a small, safe place in a troubling world."

Like an oasis in a vast desert or an island in a stormy sea.

The Baudelaires enjoyed their evening in the sanctuary they'd built together.

But in their hearts they knew that the troubling world lay just outside.

A world which, I'm sad to say, can be described in two dismal words. Custody granted.

While describing the feelings of the children, the camera visually shows what is meant by the word "sanctuary." Shadows of the children are seen as they are sitting in a small tent playing. The camera gradually zooms out and the viewers see the tent being lit as opposed to the big, dark, and disordered room they are in; thus, offering a symbolic correlation between the tent which is a physical sanctuary and the outside dark and dismal world which will get worse in the following scene when Count Olaf wins custody. The focus on the emotions of the characters continues as the events unfold themselves to the viewers and become evident when the sympathetic narrator even provides a description of the just punishment Olaf received. Significantly, despite being the film's villain, Count Olaf never got any detailed description at the beginning of the film to allow the audience to form their own perception of him. After his character has been exposed gradually and clearly to them, the narrator comments on his ending: "I am thrilled to say that Count Olaf was captured, for crimes too numerous to mention."

In Qarun, the narrator utilises a blend of psycho and free indirect thought narration throughout the play. The following extract is an example of such blend:

Narrator: But Qarun was a proud idiot, he got more stubborn,

Threatened and roared, ...

He does not know the worth of this noble Sheikh and

does not care to know!

$\mathrm{He}$ is ungrateful, stingy and arrogant.

He hates being given advice or guidance (13-14).

Unlike Snicket's description which wins the sympathy of the viewers for the 
characters, the narrator in Qarun focuses on the negative emotions and feelings of Qarun to prevent any sympathy with this character.

Similar to their introduction of the tales, the ending is also performed by both narrators. The ending of Qarun is both visually and verbally highlighted to shed light on the intended moral lessons:

[The screen suddenly shows the image of Qarun's palace breaking down. Sound effects of the earthquake and the people screaming are played] ...

The narrator: The earth opened its mouth,

It swallowed Qarun's palace.

It is now mere ruins ...

[Pointing to the people on stage] and those who wished yesterday to be like him [have his wealth] are now asking God for forgiveness (31-32).

The screen then shows the verse from the Holy Quran: "We caused the earth to swallow him and his home: he had no one to help him against God, nor could he defend himself." The ending thus visually and verbally underscores the ending of Qarun as an example that should be avoided. The ending thus runs parallel to the opening of the play. The narrator ends his tale in a way that asserts the presence of a linear pattern and a logical chronological order of events. In his final appearance, he reminds his audience of the tale and the protagonist of the work:

Narrator: Our tale has now come to an end.

How wonderful the stories taken from the Quran are!
They suit all ages and all places.

You have seen the man who was not good at heart,

Who did not help the orphans,

Was unfair to all people. ...

So, seize the opportunity now and give away some money,

Be kind and compassionate,

To have God's grace ... (33-34).

The ending intensifies the moral of the tale and echoes what the narrator affirmed in the opening scene. To borrow Zeki Saritoprak's words, "one must give away a portion of his or her wealth to the poor and needy to strike a balance between this worldly life and the afterlife" (25). The narrator clearly exemplifies Jahn's words on the narrator in Pericles, "as a perceptive moderator who introduces each of the remaining acts and eventually speaks the epilogue, closing the play's mediating frame" (672). He, thus, resembles the role of the Greek chorus that comments in the prologue and epilogue of classical works. The narrator also appeals to his young audience to reflect upon the just punishment mentioned in the Holy Quran. The young adults are again reminded that this is an authentic tale stated in the Quran. The play also ends with the intended moral lessons behind it clearly stated by the narrator who directly addresses his audience asking them to take Qarun as an example of avarice and greed.

In Lemony, the ending comes to underscore the existence of, paradoxically, parallelism and contrast with the opening of the film. Lemony announces that the children are still orphans seeking custody, but, in contrast to his earlier words on how "unfortunate" they are, he declares that 
they are "fortunate" because of their skills and talents, and more importantly, because they have each other:

There are people who know that there's always a mystery to be solved. And they take comfort in researching and writing down any important evidence.

But this story is not about such people.

This story is about the Baudelaires. And they are the sort of people who know that there's always something.

Something to invent, something to read, something to bite and something to do to make a sanctuary, no matter how small. And for this reason, I am happy to say, the Baudelaires were very fortunate indeed.

The above quote shows how the journey in Lemony between "misfortune" and "fortune" exemplifies the moral lesson of the work. Hence, the endings of both works restate the embedded moral lessons: avarice is avenged, kindness is rewarded. Ricoeur believes that "a narrative conclusion can be neither deduced nor predicted. There is no story unless our attention is held in suspense by a thousand contingencies. Hence we must follow the story to conclusion. So rather than being predictable, a conclusion must be acceptable" (The Narrative Function 277). The ending of the selected works are "acceptable" to the young viewers as they affirm the moral lessons and values implanted from the very beginning to the end. The introduction of both works led to the just punishment of the two villains: Qarun and Count Olaf, who relentlessly attempted to harm the children to win their money.

The previously discussed roles of the narrators coincide with Ryan's three distinct "pragmatic functions" of narrators: "the creative (or self-expressive), the transmissive (or performative), and the testimonial (or assertive) function" (147). These functions are elaborately described by him as follows:

The first is the creative function [which] resides in the activity of shaping and encoding the story, of forming discourse in the mind. It is the assumption that this function is being fulfilled that entitles readers and listeners to regard narrative discourse as the expression of a narratorial self. If no self is revealed in any psychological sense, the creative function still reflects on the storytelling competence of a specific individual. Without a materialization of the signs of language, however, the product of the creative function would never leave the privacy of the mind. This materialization is what I call the transmissive function, and it can take the form of either oral performance or written inscription. The third function consists of presenting the story as true of its reference world, which means accepting responsibility for the assertive statements that make up the bulk of narrative discourse. (148)

In Qarun, the three levels are strongly present. The narrator, an "overt" figure, is responsible for telling the tale of Quran which seems to be an easy task given the fact that his audience already has pre- 
existing knowledge of Qarun and his tale. The first function is clear when the narrator attempts to explain and interpret what the tale is about. To achieve this function, the narrator starts first by telling his tale introducing Qarun. The second function is clear since narration is carried out as an "oral performance" supported by Qarun's immediate presence on stage. The third function in Qarun is emphasised as the narrator recites verses from the Holy Quran; thus, proving that his tale is a real one. Thus, both the narrative and the performance, in addition to the references to the Holy Quran, validate the narrator's words achieving the third function.

In Lemony, the narrator explicitly states "it is my sad duty to document this tale." Once this line is uttered, the camera shows the reason behind the title and the word "sad" in the opening line. In fact, the opening line corresponds to the three functions suggested by Ryan. By stating that he is a writer who is "documenting" the lives of the three orphans, the protagonists of the work, the viewers understand that he is not "inventing" the tale. Besides witnessing the actions, narration in the film is presented through two media: the oral and the enacted (often the written is seen, but at a very low scale) which gives validation to the narrated tale. This duality is present because the narrator is a writer who is simultaneously narrating as he types his tale.

\section{Centralisation, Focalisation and Point of View}

What does the narrator tell/hide? An important question that is essential to pose when watching the play and the film. In the two works, events are both seen and told. Depending on narration in the works has a two-fold purpose: it allows the viewers' imagination to run free and saves them the boredom of seeing the events, and confirms the authority of the narrator who has full control over the tale. As heterodiegetic narrators, they are able to control, interrupt and assert the fictionality of the narrations. They both directly address their "narratees" at the beginning, during the tale, and at the end. Hence, their presence cast a shadow over the events and the audience is constantly reminded of them. While examining the two narrators, a significant narratological concept emerges which is "focalization ("who sees/whose point of...)" (Wout Dillen 78). Both narrators interfere reminding the audience that this is a tale. Interrupting the events shows how the threads of the tale are in their hands. With such narrators, the audience feels controlled or doomed to be told and shown a tale from their point of view. What is then edited or removed from the tale cannot be known since the narrators control the events showing what they believe to be relevant to their own tale. With young adult viewers, such narrators are often needed to help them focus on the moral lesson or message intended by the implied author. In both works, the narrators assert their control through two methods: commentary and interruption.

In Qarun, commentary is accompanied by a number of visual signs: the light dims on Qarun and the narrator moves across the stage to address the audience. The commentary almost always comes after the audience sees for themselves the scene on stage. An example is the following after Sheikh Saleh advises Qarun to give money to the poor especially that the day is a feast, but he strongly refuses and even offends the old Sheikh: 
Narrator: Exits the old Sheikh,

Hears the hungry moan,

But Qarun is still stubborn,

Iron-hearted, and never listens to

the advice of the Sheikh.

$\mathrm{He}$ is arrogant and tyrannical,

But today is the feast,

It's a distant hope [that he should

give the poor],

Let's wait and see (15).

The above commentary which emphasises the vicious nature of Qarun is repeated to pave the way for the just end of this ruthless character. It is meant to highlight Qarun's unsympathetic nature given the fact that an old man, a widow and an ill man are in dire need of money, but are mercilessly shunned and driven away by him. Even more, the backstage screen shows the parade of Qarun which contrasts very obviously with the poverty of the people. Then, the audience sees on stage how he deliberately and mercilessly drives away the poor who turn to him for help.

In the film, commentary is also associated with a number of non-verbal signs: light, camera movement and acoustic signs. Comments made by the narrator take several forms: either they occur before the events take place; thus, paving the way for the upcoming events, or they are made after the viewers have seen the action for themselves. An example of the first is evident before the children meet Count Olaf, their new custodian:

\section{I don't know}

if you've ever noticed this, but first impressions are often entirely wrong.

For instance, Klaus, when Sunny was born, didn't like her at all.
But by the time she was six weeks old, the two of them were thick as thieves.

A phrase which here means, "fetching and biting for hours on end." In the case of Count Olaf, however... Orphans! ... they were correct.

Every morning, Count Olaf would order the Baudelaires to do a great number of terrible chores.

Such commentary prepares the viewers for the coming events and for Count Olaf's constant attempts to win the children's fortune. By contrast, an example of the commentary that follows the action is when the Banker Mr. Poe comes to report the dreadful news of the parents' death and, immediately, the narrator comments on the grave news and sad feelings of the children by directly addressing the audience:

If you have ever lost someone very important to you,

then you already know how it feels. And if you haven't, you cannot possibly imagine it.

The narrator's words create a powerful effect on the viewers as they are invited to reflect upon the scene they have just seen and to relate it to their personal experience. It also creates a sense of "immediacy" as the "here and now" viewers are reminded of the fact that they are watching a film. Moreover, the commentary acts as a direct appeal to the emotions and feelings of the audience creating a strong sense of sympathy and identification with the young orphans who lost their parents and their house. In addition, the viewers begin to understand the significance of the title as this particular incident is the cause and trigger 
of all the "unfortunate events" that will follow.

In contrast to the previous examples of commentary in both works, intrusion exists only in the film. In Lemony, the narrator interrupts the events reminding the viewers that what they are seeing is a film; a representation of the events of the Baudelaires. This interruption takes place only twice: in the introduction of the film when the narrator stops the film of the happy elves singing announcing that this is not the tale/movie they will watch. The second is when their Aunt Josephine is about to die and he interferes addressing the viewers: "Well, you get the picture". A quick cut is made and we see him typing on the typewriter. Such interference is used to spare the viewers the scene when the sea deadly worms eat the aunt alive. There is an interesting example of the blend of commentary and intrusion. However, the scene is not roughly cut, as in the previously mentioned example of the death of the aunt, but there is a smooth transition to the following scene:

And just like that, the Baudelaire children became the Baudelaire orphans.

I tried to warn you.

This is an excellent opportunity to walk out of the theater,

living room or airplane where this film is being shown.

It's not too late to see a film about a happy little elf.

This commentary is done in two steps: the narrator first utters the first three lines while the camera shows the children getting out of their house which is totally burnt. Then, a very long shot used through a crane is used to show the ruined house in the midst of the surrounding houses; after that, the camera zooms out and the shot is fixed so that it becomes a photographic image of the house held in the hands of the narrator. This very smooth transition has two functions: it allows the last scene of the burnt house to become the centre of the frame and, thus, highlighting the sense of loss felt by the children. Secondly, it allows the narrator to become centralised again and to directly address the viewers interrupting the action reminding them that this is a sad tale and; thus, offers them a second chance not to watch this film.

Analysing the different instances of commentary and interruption in the play and film shows that there are several "hierarchial levels"; that there is always a transition between the now of the narrator and the now of his tale. Richardson argues that "the alternation between narration and enacted events is quite comparable in many ways to a homodiegetic narrator's shift between presenting scenes as they unfolded in his or her life and the retrospective commentary that takes place during the time of the writing, as found in the first person fictions of Dickens..." (683). The transition from the world of the narrated tale to the present world of the characters is carried out through audiovisual signs: sudden or smooth cuts and the presence of the typewriter and its sound. Examined from the perspective of narratology, the interruption made by Snicket is what Fludernik calls "metalepsis" defined as "a narrative technique in which ontological axioms, e.g. that authorial narrators live in a different world from that of their characters, are undermined with the result of destroying one's impression that the narrated world is real" (100). There are four types of "metalepsis" discussed by Fludernik "In "Scene Shift, Metalepsis, 
and the Metaleptic Mode": authorial, ontological (comprising two types) and rhetorical metalepsis. Of the four, it is the first that is applicable to Lemony. Dillan defines as follows: "reserved for passages that indicate the narrator's control over the development of the fiction he narrates, and thus foreground the fictionality of the story" (73). With such a technique, the narrator is foregrounded as the central figure in the film, even more important than the characters themselves as he is the one who controls the action. The narrator has the power to fast-forward/rewind, add/delete the events that he desires. Such power allows him to have a grip over the attention of the young adult audience.

\section{Conclusion}

The two works attempt to deliver messages to the young adults and, thus, the presence of a narrator to direct their attention to such lessons or values is essential. The narrators do not merely act as the frame of the two works, but their roles are deeper and more influential. In the works, the narrators are centralized through their constant commentary, interruption or interference. They both assert their positions as narrators in whose hands lie the representation of the tale and the narratives included. In both works, we do not see any flashbacks or recalled past events. Instead, the focus is on the present allowing the audience/viewers to witness the events and create their own viewpoint. Therefore, the events have a great impact on the viewers as they become fully immersed into the world of the characters and, therefore, eager to reach the ending of the works. The narrators tamper with the play and the film as they desire, yet they remain the focus of the audience. According to Bruner, "A narrative is composed of a unique sequence of events, mental states, happenings involving human beings as characters or actors. These are its constituents. But these constituents do not, as it were, have a life of their own. Their meaning is given by their place in the overall configuration of the sequence as a whole - its plot or fabula" (Bruner 43). Seen in relation to the previous words, the words of the narrators in both works acquire their meaning only when set against the other elements as a whole: the performance of the characters, their dialogue, the structure of the play/film and its transition from one extreme to the other, the arrangement of the scenes, the plot, the props, the nonverbal elements and the camera movement. Together, they help shed light on the diverse tasks performed by the narrators. It is because of the narrators and the way they tell their tales that "meaning is given" to their narrative and that the moral lessons are evident and crystalised in the two works.

\section{Notes}

1 All quotes from Qarun have been translated into English by the author of the paper. 


\section{Works Cited}

Abu Taleb, Asmaa. Qarun. Nubar Printing House, 2018.

Brangian, Edward and Seymour Chatman. "Narration Issues." Film Quarterly, vol. 41, no.1, 1987, pp. 63-65.

Bruner, J. Acts of Meaning. Harvard UP, 1990.

Cart, Michael. Young Adult Literature: From Romance to Realism. $3^{\text {rd }}$ ed., ALA NealSchuman, 2016.

Dillen, Wout. "Stretching the Boundaries of Narrativity on Stage: A Narratological Analysis of PaulaVogel's The Baltimore Waltz and Hot 'N' Throbbing." Style, Vol. 47, No. 1, Behavioral Economics in Fiction, Poetic Rhymes, and Narrativity on Stage (Spring 2013), pp. 69-86

Hill, Crag, editor. The Critical Merits of Young Adult Literature: Coming of Age. Routledge, 2014.

Ibn Kathir. Stories of the Prophets. Translated by Mohammed Hilmi Al Ahmed. Dar AlKotob Al-Ilmayah, 2013.

Jahn, Manfred. "Narrative Voice and Agency in Drama: Aspects of a Narratology of Drama." New Literary History, vol. 32, no. 3, 2001, pp. 659-679.

Lemony Snicket's A Series of Unfortunate Events, directed by Brad Silberling, 2004.

Patai, Raphael. The Jewish Alchemists: A History and Source Book. Princeton UP, 1994.

Prince, Gerald. Dictionary of Narratology. Nebraska UP, 2003.

Richardson, Brian. "Voice and Narration in Postmodern Drama." New Literary History, vol. 32, no. 3, 2001, pp. 681-694.

Ricoeur, P. The Narrative Function. Hermeneutics and the Human Sciences. J. B. Thompson, Cambridge UP, 1981.

--------. Time and Narrative, vol.1. Translated by Kathleen McLaughlin and David Pellauer. Chicago UP, 1984.

Ryan, Marie-Laure. "The Narratorial Functions: Breaking down a Theoretical Primitive." Narrative, vol. 9, no. 2, 2001, pp. 146-152.

Saritoprak, Zeki. "The story of Qarun (Korah) in the Qur'an and its Importance for Our Times." Poverty and Wealth in Judaism, Christianity, and Islam. Eds. Nathan R. Kollar and Muhammad Shafiq. Palgrave, Macmillan, 2016.

Steinly, Gary. "Introductory Remarks on Narratology Author." College English, vol. 38, no. 3, 1976, pp. 311-315.

Trupe, Alice. Thematic Guide to Young Adult Literature. Greenwood Press, 2006. 